\title{
HLA-A*0201 Negative
}

National Cancer Institute

\section{Source}

National Cancer Institute. HLA-A*0201 Negative. NCI Thesaurus. Code C150640.

An indication that cells expressing HLA-A*0201 have not been detected in a tissue sample. 